\title{
High-fibre and low-fat diets in diabetes mellitus
}

\author{
By P. M. DODSON. J. STOCKS, G. HOLDSWORTH AND D. J. GALTON \\ Diabetes and Lipid Fesearch Laboratory, St Bartholomew's Hospital, London ECI
}

(Received 20 February 1981-Accepted 15 May 1981)

\begin{abstract}
1. Eight insulin-dependent and eight insulin-independent diabetic patients and twenty-eight non-diabetic essential hypertensive patients were given a high-fibre, high-unrefined carbohydrate and low-fat diet for 3 months duration.

2. The effects of this dietary regimen on the patients' fasting blood glucose, hypoglycaemic therapy and weight was observed.

3. Fasting lipid profiles wert: obtained before and after 3 months on the dietary regimen, and total serum lipids and lipoprotein fractions were analysed.

4. The insulin-dependent and insulin-independent diabetic patients showed a reduction in hypoglycaemic therapy, with no significant change in fasting blood glucose. The insulin-independent and non-diabetic groups both showed significant weight loss.

5. The three groups of patients showed a significant reduction in cardiovascular risk factors with either an elevation of high-density lipoprotein (HDL)-cholesterol or a fall in low-density lipoprotein (LDL)-cholesterol and a reduction in the total cholestrorol:HDL-cholesterol value.
\end{abstract}

Many studies have reported that dietary fibre improves glucose tolerance in patients with insulin-dependent diabettes mellitus, (Kiehm et al. 1976: Jenkins et al. 1976: Miranda \& Horwitz, 1978) the greatest improvement being with guar gum (Jenkins et al. 1977) although other forms of dietary fibre had a lesser effect e.g. bran and pectin. Hockaday and his colleagues (Simpson, Mann, Eaton et al. 1979) have also shown that high-unrefinedcarbodydrate diets improve glucose tolerance in insulin-independent diabetics. In both insulin-dependent and insulin-independent diabetic patients, high-fibre diets are associated with an improvement of scme cardiovascular risk factors; e.g. low density lipoprotein (LDL) and total cholesterol.

We have studied the effects of a diet of high fibre and high unrefined carbohydrate in combination with low fat in both insulin-dependent and insulin-independent diabetic patients, in order to deterrnine the combined effect and patient acceptance during a 3 month period.

\section{EXPERIMENTAL}

Forty-four patients attending the outpatient department at the Royal Berkshire Hospital, Reading, were studied: eight insulin-dependent (type 1) diabetics (five male, three female, mean ( \pm SD) age $44 \pm 8$ years, mean \% desirable weight $109 \pm 13.5$ ), eight insulin-independent (type 2 ) diabetics (six male, two female, mean ( \pm SD) age $55 \pm 9$ years mean \% desirable weight $113 \pm 13.4$ ) on oral hypoglycaemic therapy of a sulphonyl urea or biguanide (as shown in table 2) and twenty-eight non-diabetic essential hypertensive patients used as controls (twenty-four male, four female, mean $( \pm$ SD) age $51 \pm 11$ years, mean $( \pm S D)$ weight $77.6 \pm 11.9 \mathrm{~kg}$, mean \% desirable weight $110.2 \pm 13.4$ ).

The diabetic patients were all previously treated on low carbohydrate diets which had been recommended by the hospital dietician and had stable tablet or insulin therapy for at least 1 month before the study.

The mean daily carbohydrate content of the insulin-dependent diabetics prior to the study was $158 \pm 41 \mathrm{~g}$ (range 121)-210) and of the insulin-independent diabetics was $123 \pm 16 \mathrm{~g}$ 
Table 1. Composition of modern Western and Third World diets, the modified dietary regimen used at the Royal Berkshire Hospital, and mean values obtained from dietary histories obtained from patients on the experimental dietary regimen

\begin{tabular}{|c|c|c|c|c|}
\hline & $\begin{array}{l}\text { Modern western } \\
\text { diet USA* }\end{array}$ & $\begin{array}{l}\text { Third world diet } \\
\text { (Uganda, 1930) }\end{array}$ & $\begin{array}{c}\text { Royal Berkshire } \\
\text { Hospital } \\
\text { modified diet }\end{array}$ & $\begin{array}{l}\text { Analysis of patients' } \\
\text { dietary histories } \\
\text { (mean values) }\end{array}$ \\
\hline $\begin{array}{l}\text { Total energy } \\
\text { (kcal) }\end{array}$ & $\begin{array}{c}2100-4500 \\
(8 \cdot 6-18.5 \mathrm{MJ})\end{array}$ & $\begin{array}{c}2250 \\
(9 \cdot 2 \mathrm{MJ})\end{array}$ & $\begin{array}{c}1600-1800 \\
(6.5-7.4 \mathrm{MJ})\end{array}$ & $\begin{array}{c}1400-2100 \\
(5 \cdot 8-8 \cdot 6 \mathrm{MJ})\end{array}$ \\
\hline $\begin{array}{l}\text { Fat } \\
(\% \text { dietary energy })\end{array}$ & 42 & 10 & 15 & 20 \\
\hline $\begin{array}{l}\text { Protein } \\
\text { (\% dietary energy) }\end{array}$ & 12 & 20 & 20 & 24 \\
\hline $\begin{array}{l}\text { Unrefined carbohydrate } \\
(\% \text { dietary energy) }\end{array}$ & 22 & 70 & 65 & 51 \\
\hline $\begin{array}{l}\text { Refined carbohydrate } \\
\text { (\% dietary energy) }\end{array}$ & 24 & Nil & $0-5$ & $0-5$ \\
\hline
\end{tabular}

- World Health Organization (1973).

(range 100-150). Fasting blood glucose and lipid profile were investigated in each patient on two occasions before entering the study and weight was also recorded. The modified dietary regimen, made up from readily available western foodstuffs and providing 6.5-7.4 MJ $(1600-1800 \mathrm{kcal} / \mathrm{d})$ was then commenced. The composition of the diet is shown in Table 1 and consisted of high dietary fibre $(35-40 \mathrm{~g} / \mathrm{d})$, high unrefined carbohydrate $(65 \%$ of dietary energy) and low-fat (15\% of dietary energy) when compared to a typical modern western diet (see Table 1). The composition of the modified dietary regimen was based on the analysis of the diet of the Ugandan population in 1931 (Orr \& Gilkes, 1931) in whom Trowell (1975) has subsequently reported a low incidence of diabetes mellitus. The dietary fibre intake incorporated $20 \mathrm{~g}$ guar gum/d mixed in unsweetened orange juice for the insulin-dependent diabetics, or $20 \mathrm{~g} / \mathrm{d}$ durum hard wheat bran $(480 \mathrm{~g} / \mathrm{kg}$ dietary fibre) for the maturity-onset diabetics and control patients. The patients were instructed to take the dietary fibre supplements in two equal doses, one with breakfast and the other with the evening meal.

The daily plan of the modified dietary regimen which was given to each patient is shown in Fig. 1. In addition to this, a list of foods was given to the patients which had low-fat and low-salt content and the patients were to eat wholefood products, for example, wholemeal: bread, cereals (Shredded Wheat or Weetabix), biscuits, pasta, brown rice and foods made with wholemeal flour. Refined sugar was forbidden on the dietary regimen but alcohol (particularly whisky and brandy) was permitted. Detailed dietary histories were taken on two occasions from each patient by either the hospital dietician or the author (P.M.D.), an example of which is shown in Fig. 2, and the mean values of these analyses are shown in Table 1.

A fasting blood glucose was repeated at monthly intervals and a further fasting lipid profile was taken after 3 months on the dietary regimen when the study was terminated. However two insulin-dependent diabetics did not complete the study due to hypoglycaemic episodes requiring acute admission to hospital despite reduction in insulin therapy.

Serum cholesterol and triglyceride concentrations were measured by semi-automated fluorometric techniques, Technicon Instruments Co. Ltd and Liebermann-Burchard's reagent being used for cholesterol (normal range 4.5-6.7 mmol/1; coefficient of variation 2.8) and Cramp \& Robertson's (1968) method being used for triglyceride (normal range 
Table 2. Clinical details and changes in insulin-dependent and insulin-independent diabetic patients on the modified regimen

(Two insulin-independent diabetics did not complete the study owing to hypoglycaemia)

\begin{tabular}{|c|c|c|c|c|c|c|c|}
\hline \multirow[b]{2}{*}{ Patient group } & & \multicolumn{2}{|c|}{$\begin{array}{l}\text { Before dietary } \\
\text { regimen }\end{array}$} & \multicolumn{2}{|c|}{$\begin{array}{l}\text { On dietary } \\
\text { regimen }\end{array}$} & \multirow{2}{*}{$\begin{array}{l}\text { Mean } \\
\text { change }\end{array}$} & \multirow{2}{*}{$\begin{array}{c}\text { Statistical } \\
\text { significance } \\
\text { of change }\end{array}$} \\
\hline & & Mean & SD & Mean & SD & & \\
\hline \multirow[t]{2}{*}{$\begin{array}{l}\text { Insulin-dependent } \\
\text { diabetics }(n \text { 6) }\end{array}$} & $\begin{array}{l}\text { Fasting blood } \\
\text { glucost: }(\mathrm{mmol} / \mathrm{l})\end{array}$ & $11 \cdot 7$ & $1 \cdot 2$ & $10 \cdot 0$ & $1 \cdot 1$ & $-1 \cdot 7$ & NS \\
\hline & $\begin{array}{l}\text { Wt. (kg) } \\
\text { Insulin therapy } \\
\text { (units) }\end{array}$ & $\begin{array}{l}71 \\
41\end{array}$ & $\begin{array}{l}5 \cdot 8 \\
7 \cdot 4\end{array}$ & $\begin{array}{l}67 \\
32\end{array}$ & $\begin{array}{l}4.8 \\
5 \cdot 4\end{array}$ & $\begin{array}{l}-4 \cdot 0 \\
-9 \cdot 0\end{array}$ & $\begin{array}{c}\text { NS } \\
P<0.05\end{array}$ \\
\hline $\begin{array}{l}\text { Insulin-independent } \\
\text { diabetics }(n 8)\end{array}$ & $\begin{array}{l}\text { Fasting blood } \\
\text { glucos: (mmol/l) } \\
\text { Wt (kg) } \\
\text { Oral therapy } \\
\text { (biguanide and } \\
\text { sulphonyl-urea) } \\
\text { no. of tablets }\end{array}$ & $\begin{array}{r}7 \cdot 9 \\
79 \cdot 6 \\
14^{*}\end{array}$ & $\begin{array}{l}0 \cdot 7 \\
5 \cdot 5 \\
-\end{array}$ & $\begin{array}{r}7 \cdot 7 \\
72 \cdot 1 \\
3 \dagger\end{array}$ & $\begin{array}{l}0.4 \\
5.0 \\
-\end{array}$ & $\begin{array}{l}-0.2 \\
-7.4 \\
-11\end{array}$ & $\begin{array}{c}\text { NS } \\
P<0.01 \\
-\end{array}$ \\
\hline \multirow{2}{*}{$\begin{array}{l}\text { Non-diabetic } \\
\text { control patients } \\
(n \text { 28) }\end{array}$} & $\begin{array}{l}\text { Fasting blood } \\
\text { glucose (mmol/l) }\end{array}$ & $5 \cdot 2$ & 0.8 & $5 \cdot 0$ & $1 \cdot 4$ & -0.2 & NS \\
\hline & Wt (kg) & 77.6 & 11.9 & 73.5 & $10 \cdot 6$ & -3.9 & NS \\
\hline
\end{tabular}

NS, not significant; statistics by Student's paired $t$ test.

- Daonil $17.5 \mathrm{mg}$, Diabenese $250 \mathrm{mg}$, Metformin $850 \mathrm{mg} \times 4$, Glibenese $5 \mathrm{mg}$.

+ Daonil $2.5 \mathrm{mg} \times 2$, Diabenese $250 \mathrm{mg}$.

Daily allowances

Breakfast

Mid-morning and mid-afternoon

Lunch

Evening meal
$400 \mathrm{ml}$ Marvel dried skimmed milk.

$28 \mathrm{~g}$ Outline margarine.

Tea or coffee with milk from daily allowance (D.A).

Cereal-small dish with milk from D.A.

One slice wholemeal bread with margarine from D.A.

Tea or coffee with milk from D.A.

One plain wholemeal biscuit.

$112 \mathrm{~g}$ meat or $170 \mathrm{~g}$ fish or one egg, with generous portions of vegetables.

Two large slices of wholemeal bread with margarine from D.A.

One portion of fresh, frozen or tinned fruit.

Tea or coffee with milk from D.A.

$112 \mathrm{~g}$ meat or $170 \mathrm{~g}$ fish or one egg with generous portions of vegetables which include: either three medium jacketed potatoes or $84 \mathrm{~g}$ wholemeal pasta or $84 \mathrm{~g}$ brown rice.

One portion of fresh, frozen or tinned fruit.

Tea or coffee with milk from D.A.

Fig. 1. The daily plan of the dietary regimen given to all patients. 
Breakfast

Mid-morning and mid-afternoon Lunch

Evening meal

Night-time
Shredded wheat with $10 \mathrm{~g}$ of hard wheat bran and milk from D.A.

One large slice of wholemeal bread.

One cup of tea.

Cup of tea or coffee with two plain wholemeal biscuits.

Baked jacketed potato with $112 \mathrm{~g}$ of cold beef with lettuce, tomato and cucumber.

One apple.

Boiled new potatoes with $160 \mathrm{~g}$ of grilled haddock with peas sprinkled with chopped parsley and lemon juice.

Unsweetened orange juice with $10 \mathrm{~g}$ of hard wheat bran.

One cup of cocoa made with milk from D. A.

One wholemeal biscuit.

Fig. 2. A typical dietary history from an insulin-independent diabetic on the modified dietary regimen.

0.7-2.1 mmol/1; coefficient of variation $2 \cdot 9$ ). High-density lipoprotein (HDL)-cholesterol was measured in the supernatant fraction following precipitation by heparin ( $250 \mathrm{units} / 50 \mu \mathrm{l})$ and $1 \mathrm{M}$-manganese chloride $(50 \mu \mathrm{l})$ Warnick \& Albers, 1978). Very low-density lipoprotein (VLDL) cholesterol was measured following precipitation by sodium dodecyl sulphate $(100 \mathrm{~g} / 1 ; 75 \mu \mathrm{l})$. LDL-cholesterol was obtained by subtracting the sum of HDL- and VLDL-cholesterol values from the total serum cholesterol. Statistical analysis was performed using the Student's paired $t$ test.

\section{RESULTS}

The changes in therapy, weight and fasting blood glucose for both insulin-dependent and insulin-independent diabetics $(n)$ ) are shown in Table 2. The diet seemed palatable to patients as the composition derived from the dietary histories was similar to the intended regimen (see Table 1) apart from a lower mean unrefined carbohydrate intake $(51 \mathrm{v.} \mathrm{65 \%}$ of dietary energy). Patients tolerated the diet extremely well. This is shown by the high number of patients maintaining the dietary regimen with similar drug therapy after a two year period; four of the original six insulin-dependent diabetics, six of the original eight insulin-independent diabetics and twenty-two of the original twenty-eight essential hypertensive patients.

Initially the majority of patients found the dietary regimen bland owing to the low fat content, but most patients became adjusted to the dietary changes after a three-week period. There were no complaints made to the author (P. M. D.) about the high-fibre content of the diet, in particular most patients found the durum hard wheat bran palatable.

The six insulin-dependent diabetics who completed the study had a significant fall in mean insulin therapy of 9 units/d (range 4-20 units/d) although this was not accompanied by a significant weight loss or reduction in blood glucose. One patient required reduction of 20 units/d of monocomponent insulins during the first $2 \mathrm{~d}$ of the regimen, in order to prevent marked hypoglycaemia. These changes were accompanied by significant lipid changes: LDL-cholesterol $(P<0.05)$ and in the total cholesterol:HDL-cholesterol $(P<0.05)$ as shown in Table 3. There was a reduction of mean total serum cholesterol from 7.5 to $5.5 \mathrm{mmol}$ but this did not reach statistical significance $(P<0 \cdot 1)$. There was no significant alteration of total serum triglyceride (from 1.13 to $1.06 \mathrm{mmol} / \mathrm{l}$ ).

The insulin-independent diabetic patients had a mean weight loss of $7.4 \mathrm{~kg}$ after 3 months 
Table 3. Changes in lipoprotein levels of insulin-dependent and insulin-independent diabetics and non-diabetic essential hypertensive control patients on the modified dietary regimen

\begin{tabular}{|c|c|c|c|c|c|c|}
\hline \multirow[b]{2}{*}{ Patient group } & \multirow[b]{2}{*}{ Serum cholesterol } & \multicolumn{2}{|c|}{ Before dietary reigmen } & \multicolumn{2}{|c|}{$\begin{array}{l}\text { After } 3 \text { months } \\
\text { on dietary regimen }\end{array}$} & \multirow{2}{*}{$\begin{array}{c}\text { Statistical } \\
\text { significance of } \\
\text { difference between } \\
\text { values }\end{array}$} \\
\hline & & Mean & SE & Mean & SE & \\
\hline $\begin{array}{l}\text { Insulin-dependent } \\
\text { diabetics }(n 6)\end{array}$ & $\begin{array}{l}\text { Total } \\
\text { HDL } \\
\text { LDL } \\
\text { Total cholesterol: } \\
\text { HDL cholesterol } \\
\text { Total triglyceride }\end{array}$ & $\begin{array}{l}7 \cdot 5 \\
1 \cdot 7 \\
5 \cdot 1 \\
4 \cdot 5 \\
1 \cdot 1\end{array}$ & $\begin{array}{l}0.85 \\
0.17 \\
0.1\end{array}$ & $\begin{array}{l}5 \cdot 47 \\
1 \cdot 52 \\
3 \cdot 35\end{array}$ & $\begin{array}{l}0.37 \\
0.19 \\
0.4\end{array}$ & $\begin{array}{c}\text { NS } \\
\text { NS } \\
P<0.05 \\
P<0.05 \\
\quad \text { NS }\end{array}$ \\
\hline $\begin{array}{l}\text { Insulin-independent } \\
\text { diabetics }(n 8)\end{array}$ & $\begin{array}{l}\text { Total } \\
\text { HDL } \\
\text { LDL } \\
\text { Total chol zsterol: } \\
\text { HDL cholesterol } \\
\text { Total triglyceride }\end{array}$ & $\begin{array}{l}5 \cdot 73 \\
0 \cdot 67 \\
3 \cdot 36 \\
7 \cdot 7 \\
2 \cdot 17\end{array}$ & $\begin{array}{l}0.67 \\
0.07 \\
0.36 \\
0.95 \\
0.6\end{array}$ & $\begin{array}{l}5 \cdot 74 \\
1.07 \\
3 \cdot 57 \\
5 \cdot 7 \\
1.66\end{array}$ & $\begin{array}{l}0.34 \\
0.12 \\
0.3 \\
0.58 \\
0.3\end{array}$ & $\begin{array}{c}\text { NS } \\
P<0.01 \\
\text { NS } \\
P<0.02 \\
\quad \text { NS }\end{array}$ \\
\hline $\begin{array}{l}\text { Non-diabetic essential } \\
\text { hypertensive control } \\
\text { patients ( } n \text { 28) }\end{array}$ & $\begin{array}{l}\text { Total } \\
\text { HDL } \\
\text { LDL } \\
\text { Total cholesterol: } \\
\text { HDL cholesterol } \\
\text { Total triglyceride }\end{array}$ & $\begin{array}{l}5 \cdot 74 \\
0 \cdot 91 \\
3 \cdot 85 \\
7 \cdot 3 \\
1 \cdot 64\end{array}$ & $\begin{array}{l}0.25 \\
0.07 \\
0.27 \\
0.6 \\
0.11\end{array}$ & $\begin{array}{l}5 \cdot 46 \\
1 \cdot 17 \\
3 \cdot 56\end{array}$ & $\begin{array}{l}0.25 \\
0.07 \\
0.23\end{array}$ & $\begin{array}{l}\text { NS } \\
P<0.01 \\
\quad \text { NS }\end{array}$ \\
\hline
\end{tabular}

NS, not significant; statistical analysis by Student's paired $t$ test.

HDL, hig.-density lipoprotein; LDL, low-density lipoprotein.

on the dietary regimen accompanied by a considerable reduction in biguanide and sulphonyl-urea drug therapy (see Table 2). Two patients however were of ideal weight prior to study and did not lose weight on the dietary regimen, but they were able to discontinue drug therapy. These changes were accompanied by a significant rise in HDL-cholesterol $(P<0.01)$ and a significant decrease in the total cholesterol:HDL $(P<0.05)$. There was a reduction of total serum triglyceride from $2 \cdot 17 \pm 0.6$ to $1.66 \pm 0.3 \mathrm{mmol}$ although this did not reach statistical significance. The control non-diabetic patients showed a mean weight loss of $4 \mathrm{~kg}$ after 3 months on the dietary regimen, but there was no change in fasting blood glucose. The hypotensive responses of these non-diabetic patients on this dietary regimen have been reported elsevhere (Dodson \& Humphreys, 1981). These patients showed significant changes in blcod lipids similar to the insulin-independent diabetics with an increase of HDL-cholesterol $(P<0.01)$ and a significant decrease in the total cholesterol:HDL-cholesterol $(P<0.001)$ and LDL-cholesterol:HDL-cholesterol $(P<0-01)$. There was no change in total serum triglyceride (from 1.64 to $1.62 \mathrm{mmol} / \mathrm{l}$ ).

\section{DISCUSSION}

The clinical changes observed in our diabetic patients are in accordance with other studies of high-fibre or high-unrefined-carbohydrate regimens which were not combined with low fat intake (Kiehm et al. 1976; Jenkins, Wolever, Leeds et al. 1978; Jenkins, Wolever, Nineham et al. 1978; Miranda \& Horwitz, 1978; Simpson, Mann, Eaton et al. 1979). The dietary therapy was not iscienergetic with the patients' previous low-carbohydrate regimens and this may have played a part in the significant weight loss of the insulin-independent diabetics and hence the reduction of drug therapy in this group. Dietary fibre is however 
known to reduce the blood glucose concentrations during glucose tolerance tests in normal subjects and reduce serum insulin concentrations. This effect is greatest with the more viscous fibre preparations e.g. guar gum. The improvement in the insulin-dependent diabetics may be mainly due to the guar gum rather than the other aspects of our dietary regimen but the low fat intake may have contributed to the lipid changes and improvement of cardiovascular risk factors, in particular the total cholesterol:HDL-cholesterol ratio and the LDL-cholesterol.

The insulin-independent diabetics and control non-diabetic patients both showed a rise in HDL-cholesterol in contrast to previous studies with high-fibre diets (Jenkins, Wolever, Nineham et al. 1978; Simpson, Mann, Eaton et al. 1979). This suggests that the low fat intake may be partly responsible for these changes especially as HDL-cholesterol levels have been shown to be unrelated to diabetic controls (Kennedy et al. 1978).

The major conclusion of this study is that improved diabetic control in both insulindependent and insulin-independent diabetics may be obtained on a dietary regimen of high fibre, unrefined carbohydrate and low fat and this may be accompanied by alterations in serum concentrations of cholesterol containing lipoproteins which may contribute to an over-all reduction in risk factors for cardiovascular disease.

A recent survey of dietary policy in British diabetic clinics has shown that carbohydrate restriction with the use of carbohydrate exchange units is predominant (Truswell et al. 1975), but our study gives further support for the use of dietary regimens of high unrefined carbohydrate combined with a high fibre content. The addition of a low fat intake to these regimens may be valuable in encouraging weight loss and improvement in cardiovascular risk factors in insulin-independent diabetic patients.

The authors wish to thank the staff of Loddon Ward, Dr E. V. Cox, Mrs O. Patrick (Royal Berkshire Hospital) for their considerable help with this study and Miss J. London for secretarial help.

\section{REFERENCES}

Cramp, D. C. \& Robertson, G. (1968). Analyt. Biochem. 25, 246.

Dodson, P. M. \& Humphreys, D. (1981). Western Diseases: their emergence and treatment. Ch. 24. [Trowell and Burkitt editors].

Jenkins, D. J. A., Leeds, A. R., Gassull, M. A., Cocher, B. \& Alberti, K. G. G. M. (1977). Ann. intern. Med. 86, 20.

Jenkins, D. J. A., Leeds, A. R., Wolever, T. M. S., Goff, D. V., Alberti, K. G. G. M., Gassull, M. A. \& Hockaday, T. D. R. (1976). Lancet ii, 172

Jenkins, D. J. A., Wolever, T. M. S., Leeds, A. R., Gassull, M. A., Haisman, P., Dilawari, J., Goff, D. V., Metz, G. L. \& Alberti, K. G. G. M. (1978). Br. med. J. ii, 1744.

Jenkins, D. J. A., Wolever, T. M. S. \& Nineham, R. (1978). Br. med. J. i, 1392.

Kennedy, A. L., Lappin, T. R. J., Lavery, T. D., Hadden, D. R., Weaver, J. A. \& Montgomery, D. A. D. (1978). Br. med. J. ii, 1191.

Kiehm, T. G., Anderson, J. W. \& Ward, K. (1976). Am. J. clin. Nutr. 29, 895.

Miranda, P. M. \& Horwitz, D. L. (1978). Ann. intern. Med. 88, 482.

Orr, J. B. \& Gilkes, J. L. (1931). Med. Res. Counc. Spec. Rep. no. 135 p.29.

Simpson, R. W., Mann, J. I. \& Eaton, J. (1979). Br. med. J. ii, 523.

Simpson, R. W., Mann, J. I., Eaton, J., Moore, R. A., Carter, R. \& Hockaday, T. D. R. (1979). Br. med. J. i, 1753.

Technicon Instruments Co. Ltd. Technicon Method no. N77. Basingstoke, Hants: Technicon Instruments Co. Ltd.

Trowell, H. C. (1975). Diabetes 24, 762.

Truswell, A. S., Thomas, B. J. \& Brown, A. M. (1975). Br. med. J. iv, 7.

Warnick, G. R. \& Albers, J. J. (1978). J. Lipid Res. 19, 65.

W. H. O. Expert Committee (1973). Wld Hlth Org. tech. Rep. Ser. No. 522. 